\title{
Oxygen-blown operation of the TwoStage Viking gasifier
}

Gadsbøll, Rasmus Østergaard; Sárossy, Zsuzsa ; Jørgensen, Lars; Ahrenfeldt, Jesper; Henriksen, Ulrik Birk

\section{Published in:}

Energy

Link to article, DOI:

10.1016/j.energy.2018.06.071

Publication date:

2018

Document Version

Peer reviewed version

Link back to DTU Orbit

Citation (APA):

Gadsbøll, R. Ø., Sárossy, Z., Jørgensen, L., Ahrenfeldt, J., \& Henriksen, U. B. (2018). Oxygen-blown operation of the TwoStage Viking gasifier. Energy, 158, 495-503. https://doi.org/10.1016/j.energy.2018.06.071

\section{General rights}

Copyright and moral rights for the publications made accessible in the public portal are retained by the authors and/or other copyright owners and it is a condition of accessing publications that users recognise and abide by the legal requirements associated with these rights.

- Users may download and print one copy of any publication from the public portal for the purpose of private study or research.

- You may not further distribute the material or use it for any profit-making activity or commercial gain

- You may freely distribute the URL identifying the publication in the public portal

If you believe that this document breaches copyright please contact us providing details, and we will remove access to the work immediately and investigate your claim 


\section{Accepted Manuscript}

Oxygen-blown operation of the TwoStage Viking gasifier

Rasmus Østergaard Gadsbøll, Zsuzsa Sárossy, Lars Jørgensen, Jesper Ahrenfeldt, Ulrik Birk Henriksen

PII: $\quad$ S0360-5442(18)31136-8

DOI: $\quad$ 10.1016/j.energy.2018.06.071

Reference: $\quad$ EGY 13113

To appear in: $\quad$ Energy

Received Date: $\quad 06$ April 2018

Accepted Date: $\quad 11$ June 2018

Please cite this article as: Rasmus Østergaard Gadsbøll, Zsuzsa Sárossy, Lars Jørgensen, Jesper Ahrenfeldt, Ulrik Birk Henriksen, Oxygen-blown operation of the TwoStage Viking gasifier, Energy (2018), doi: 10.1016/j.energy.2018.06.071

This is a PDF file of an unedited manuscript that has been accepted for publication. As a service to our customers we are providing this early version of the manuscript. The manuscript will undergo copyediting, typesetting, and review of the resulting proof before it is published in its final form. Please note that during the production process errors may be discovered which could affect the content, and all legal disclaimers that apply to the journal pertain. 


\title{
Oxygen-blown operation of the TwoStage Viking gasifier
}

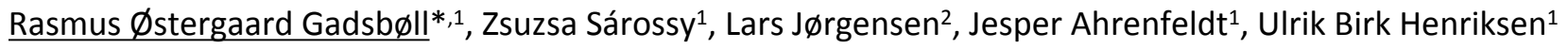

${ }^{1}$ Technical University of Denmark, Department of Chemical and Biochemical Engineering, Frederiksborgvej 399, 4000 Roskilde, Denmark

2Danish Gas Technology Centre, Dr Neergaards vej 5, $2970 \mathrm{H} \varnothing$ rsholm, Denmark

*Corresponding author, Tel: +4560668815, E-mail: rgad@kt.dtu.dk

\begin{abstract}
The TwoStage Viking gasifier from the Technical University of Denmark is being further developed for biofuel synthesis applications. In order to optimize the gasification process, it is suggested to apply an $\mathrm{O}_{2-}$ $\mathrm{CO}_{2}$ gas mixture as gasification medium, instead of air, to limit $\mathrm{N}_{2}$-dilution of the product gas. It is found through a modeling study that the system is expected to achieve operating conditions in the range of airblown operation, when $21 \mathrm{v} \% \mathrm{O}_{2}$ in $\mathrm{CO}_{2}$ is applied, and nearly identical parameters as the concentration is increased to $30 \mathrm{v} \%$. An experimental campaign with the $80 \mathrm{~kW}_{\text {th }}$ Viking pilot plant using $21 \mathrm{v} \%$ oxygen confirms this, as operation temperatures are seen to slightly decrease the partial oxidation (POX) temperature by $52-69^{\circ} \mathrm{C}$ and grate temperature by $31-36^{\circ} \mathrm{C}$. Tests with $25 \mathrm{v} \%$ oxygen were also carried out with slightly higher temperatures. Detailed gas analysis showed that $\mathrm{N}_{2}$ had effectively been reduced to a few percent and that tar and sulphur levels were similar to the very high standards of the air-blown operation: only a few $\mathrm{mg} / \mathrm{Nm}^{3}$ of tar and $<3 \mathrm{ppm}$ sulphur were detected. The lone gas cleaning, a bag filter, was found to be virtually inactive for capturing these impurities. Hence, the gasifier had been successfully demonstrated with $\mathrm{O}_{2}-\mathrm{CO}_{2}$ mixtures and is expected to be able to maintain its simple design, whilst enabling very high system efficiency.
\end{abstract}

Keywords: Biomass gasification, Two-stage gasifier, Thermodynamic analysis, Experimental, Gas quality

\section{Introduction}

It is very cost-effective to use biomass-based energy to reduce the impact on climate change, because it to a large extent can be directly utilized into the current fossil infrastructure. Biomass as a flexible resource can be used for heat and power production, but is especially relevant as a carbon source for transport fuels. The fuels can be produced in a number of ways, but the thermal gasification platform offers maximum fuel and product flexibility along with very high conversion efficiency.

The production of biofuels via biomass gasification is a well-studied area and there are a number of limitations and challenges in this coupling of technologies which are namely associated with gas quality. Synthesis reactors are very sensitive to harmful gas impurities such as tars and inorganics and while no hard conclusions can be made on tolerances ${ }^{1}$ some overall considerations can be made. These reactors utilize catalytic material at elevated temperatures of $\approx 200-700^{\circ} \mathrm{C}$ for synthesis [1][2][3], which are typically in the range of the dew points of tar species in the product gas at $\approx 200-500^{\circ} \mathrm{C}$, which can cause fouling of

\footnotetext{
${ }^{1}$ Tolerances for gas impurities are set based on catalyst, operating conditions and economic analysis and will vary
} 
equipment via condensation [4][5][6] and deactivate catalysts via carbon deposition [1][7]. Hence tar concentrations should be kept very low, in range of $<100 \mathrm{mg} / \mathrm{Nm}^{3}$, depending especially on the dew point at the given conditions when applying catalytic reactors [1][8]. Sulphur and chlorine are both poisons to catalyst reactors and should be removed to $<0.1-1.0 p p m v$ and preferably completely removed to ensure years of catalyst lifetime [9][10].

Another critical gas component, nitrogen $\left(\mathrm{N}_{2}\right)$ is of special interest when coupling gasification and biofuel synthesis. It is especially central when synthesizing gaseous fuels such as synthetic natural gas (SNG), as nitrogen seperation is expensive and dilution of the gas product might bring the Wobbe index and relative density out of the limits of the local natural gas grid². This typically limits the nitrogen content to a few percent of the final product. As an inert gas, nitrogen is also problematic as it will increase the size of the costly synthesis reactors and is recommended around $<2 \mathrm{v} \%[10]$.

\subsection{Modifying the TwoStage Viking gasifier}

The TwoStage Viking gasifier has been developed for many years at the Technical University of Denmark [11]. The air-blown downdraft system is designed with separate pyrolysis and gasification, with a partial oxidation (POX) in between and is namely characterized by its ability to process biomass into product gas at a very high cold gas efficiency of $87-90 \%$ (dry) and a very low tar content of $<0.1 \mathrm{mg} / \mathrm{Nm}^{3}$ [12][13]. The plant is presented in detail in Section 3.1. In order to develop the fuel synthesis application platform of the system, oxygen-blown operation is desired to avoid nitrogen dilution of the product gas - which coupled with the high efficiency and low tar content would make the system ideal for biofuel production. This study will therefore investigate an oxygen-blown configuration of the gasifier system.

The oxygen is initially projected to be used with a carrier gas such as $\mathrm{CO}_{2}$ or steam in order to ease the implementation, obtain operating parameters similar to air and protect equipment, as it acts as a thermal buffer during oxidation and reduces potential erosion from the hot oxygen flow in the heat exchanger and piping. $\mathrm{CO}_{2}$ is initially preferred over steam as carrier gas, as it: 1 ) can be easily implemented from gas bottles; 2 ) is much less energy intense (no need for vaporization) to implement; 3 ) and can possibly be recycled from a downstream product upgrader $\left(\mathrm{CO}_{2}\right.$ separator $)$ and led back to the POX.

Replacing $\mathrm{N}_{2}$ with $\mathrm{CO}_{2}$ is expected to affect the POX zone, as the gases have significantly different properties - see Error! Reference source not found.. While no studies have been found on $\mathrm{O}_{2}-\mathrm{CO}_{2}$ partial oxidation of pyrolysis gas, several references [14][15][16][17][18] have dealt with flame studies of $\mathrm{O}_{2}-\mathrm{CO}_{2}$ burners in oxy-fuel combustion of coal. The main differences between these burners and typical air burners are related to the gas properties that can cause ( $21 \mathrm{v} \% \mathrm{O}_{2}$ and similar flow rates as reference):

- Higher flame instability and flame retarding via a lower flame propagation speed [14][15][17]

- Generally lower gas temperatures of $\approx 100-200^{\circ} \mathrm{C}[15][16]$

- Increased diffusion resistance of $\mathrm{CO}_{2}$ that can cause a more compact flame [16]

- Similar operational parameters for air and $\mathrm{O}_{2}-\mathrm{CO}_{2}$ are reached at $\mathrm{O}_{2}$ concentrations of $28-35 \mathrm{v} \%$ [14][15][16][17]

\footnotetext{
${ }^{2}$ According to Danish law, the Wobbe Index must be higher than $50.76 \mathrm{MJ} / \mathrm{Nm}^{3}$ (HHV) and the relative density must be higher than 0.555 [34].
} 
Thus it will be important for the POX zone to optimize the mixing/contact between reactants to obtain a stable flame and maximize the tar exposure to high-temperatures in the potentially smaller flame zone, which will be even more important as the temperature is expected to decrease.

\begin{tabular}{l|ccc} 
& $\begin{array}{c}\text { Density } \\
{\left[\mathrm{kg} / \mathrm{m}^{3}\right]}\end{array}$ & $\begin{array}{c}\text { Heat capacity } \\
{[\mathrm{J} / \mathrm{mol}-\mathrm{K}]}\end{array}$ & $\begin{array}{c}\text { Mass diffusion coefficient of } \mathrm{O}_{2} \text { in } \mathrm{N}_{2} / \mathrm{CO}_{2} \\
{\left[\mathrm{~m}^{2} / \mathrm{s}\right]}\end{array}$ \\
\hline $\mathrm{N}_{2}$ & 0.244 & 34.18 & $1.7 \cdot 10^{4}$ \\
$\mathrm{CO}_{2}$ & 0.383 & 57.83 & $1.3 \cdot 10^{4}$ \\
Ratio $\mathrm{N}_{2} / \mathrm{CO}_{2}$ & 0.640 & 0.59 & 1.31
\end{tabular}

Table 1 - Properties of $\mathrm{N}_{2}$ and $\mathrm{CO}_{2}$ at $850^{\circ} \mathrm{C}$ and 1 bar [18]

Gasification with $\mathrm{O}_{2}-\mathrm{CO}_{2}$ mixtures has been studied on several occasions and compared to air-blown operation. Pohorely et al. [19] studied air and $\mathrm{O}_{2}-\mathrm{CO}_{2}\left(21 \mathrm{v} \% \mathrm{O}_{2}\right)$ gasification in a limestone-fed bubbling fluid bed at $850^{\circ} \mathrm{C}$ and found that replacing $\mathrm{N}_{2}$ with $\mathrm{CO}_{2}$ generally heightens both carbon conversion and cold gas efficiency compared to air. This could partially be due to an increased inlet energy content, as the $\mathrm{CO}_{2}$-mix has a higher heat capacity and same inlet temperature as the air. Higher $\mathrm{CO}$ and lower $\mathrm{H}_{2}$ yields were also found, likely due to a shift in the water-gas shift equilibrium. Tar and light hydrocarbon concentrations were found to be significantly higher for $\mathrm{O}_{2}-\mathrm{CO}_{2}$ operation, which the authors explain by increased $\mathrm{CO}$ and $\mathrm{CO}_{2}$ partial pressures that could shift the reforming reaction equilibrium away from conversion. Similar findings of carbon conversion, effciency and $\mathrm{CO}_{2}$ and $\mathrm{H}_{2}$ yields were found by Hanaoka et al. [20]. The study gasifies aquatic biomass at $900^{\circ} \mathrm{C}$ in a downdraft fixed bed reactor with $\mathrm{O}_{2}-\mathrm{CO}_{2}$ and $\mathrm{O}_{2}$ He operation and also found that an increased $\mathrm{CO}_{2}$ flow caused larger concentrations of sulphur species $\left(\mathrm{H}_{2} \mathrm{~S}, \mathrm{COS}\right)$, which could be related to increased carbon conversion, as the sulphur content of the char were found to be relatively high.

This study will present the use of $\mathrm{O}_{2}-\mathrm{CO}_{2}$ in the TwoStage Viking gasifier and compare it to its typical airblown operation - both via mathemcatical modeling and experimentally. An experimental campaign will show the effects on the operating conditions of the partial oxidation and the char bedm, and also assess the impact on gas quality including gas composition, tars and sulphur compounds. These aspects are not well-studied and will be investigated further here as a link in the development of the TwoStage gasifier and further development towards fuel synthesis applications.

\section{Modeling $\mathrm{O}_{2}$ - $\mathrm{CO}_{2}$-blown TwoStage gasification}

In order to project and plan out experimental work, the TwoStage Viking gasifier is modeled and projected with air and $\mathrm{O}_{2}-\mathrm{CO}_{2}$ mixtures. The core process is modeled via three main components: pyrolyzer, POX and gasifier. The thermodynamic modeling is carried out in DNA (Dynamic Network Analysis) that is a zerodimensional modeling tool for simulating energy systems [21][22].

Initially a model using air is constructed and calibrated to match current gasifier data. The main assumptions are given in Error! Reference source not found. and are mainly based on the very detailed experimental campaign report by Bentzen et al. [13]. Note that this report deals with a previously constructed, but very similar, TwoStage gasifier plant. The pyrolysis features a reactor that based on atomic 
balances and input calculates a char and volatile fraction at the specified temperature. The POX and gasifier utilizes Gibbs minimization for calculating the gas composition and process parameters.

\begin{tabular}{|c|c|}
\hline Fuel $^{a}$ & $\begin{array}{l}49 \% \text { moisture, } 20^{\circ} \mathrm{C} \text {, composition: } \mathrm{C}=49 \% \mathrm{H}=6 \% \mathrm{O}=44 \% \mathrm{~N}=0.2 \% \\
\text { Ash }=0.8 \% \text { (balance) } \mathrm{LHV}=18.28 \mathrm{MJ} / \mathrm{kg} \text { (dry) }\end{array}$ \\
\hline Pyrolyzer & $\begin{array}{l}\text { Volatiles are assumed to have a } \mathrm{H}_{2} \text { and } \mathrm{CH}_{4} \text { content of } 5 \mathrm{v} \% \text { and } 13 \mathrm{v} \% \text { [13], } \\
\text { tars are represented by } \mathrm{n} \text {-hexane }\left(\mathrm{C}_{6} \mathrm{H}_{14}\right) \text {, char yield of } 25 \% \text { [23], } 1 \% \text { heat loss } \\
\text { of fuel input, } \mathrm{LHV}_{\text {in }}=\mathrm{LHV}_{\text {out }} \text {, outlet temperature of volatiles and char }=600^{\circ} \mathrm{C} \\
\text { Char composition: } \mathrm{C}=93 \% .0 \mathrm{H}=2.2 \% \mathrm{~N}=0.2 \% \mathrm{HHV}=33.6 \mathrm{MJ} / \mathrm{kg} \text { (dry) [23] }\end{array}$ \\
\hline Gasification media & $\begin{array}{l}\text { Air: } \mathrm{O}_{2}=21 \% \mathrm{~N}_{2}=77 \% \mathrm{H}_{2} \mathrm{O}=1 \% \mathrm{Ar}=1 \%, \mathrm{O}_{2}-\mathrm{CO}_{2}: \mathrm{O}_{2}=21 \% \mathrm{CO}_{2}=79 \%, 20^{\circ} \mathrm{C} \text { input, } \\
450^{\circ} \mathrm{C} \text { after heat exchanger }\end{array}$ \\
\hline Partial oxidation & $\begin{array}{l}\text { Assumes thermal equilibrium at outlet temperature via Gibbs minimization of } \\
\text { volatiles-air mixture - method described in [24][25]. }\end{array}$ \\
\hline Gasifier & $\begin{array}{l}3 \% \text { fuel input heat loss [13], gas outlet thermal equilibrium }=800^{\circ} \mathrm{C} \text {, gas } \\
\text { composition calculated via chemical equilibrium (water-gas shift), carbon } \\
\text { conversion }=99 \% \text { when using air [12], pressure loss is } 30 \mathrm{mbar} \text {, outlet } \\
\text { temperature }=750^{\circ} \mathrm{C}\end{array}$ \\
\hline
\end{tabular}

The model calibration included adjusting gasifier equilibrium temperature and allocating the total heat loss of $4 \%$ on to the pyrolyzer and gasifier. The air-blown model is pictured in

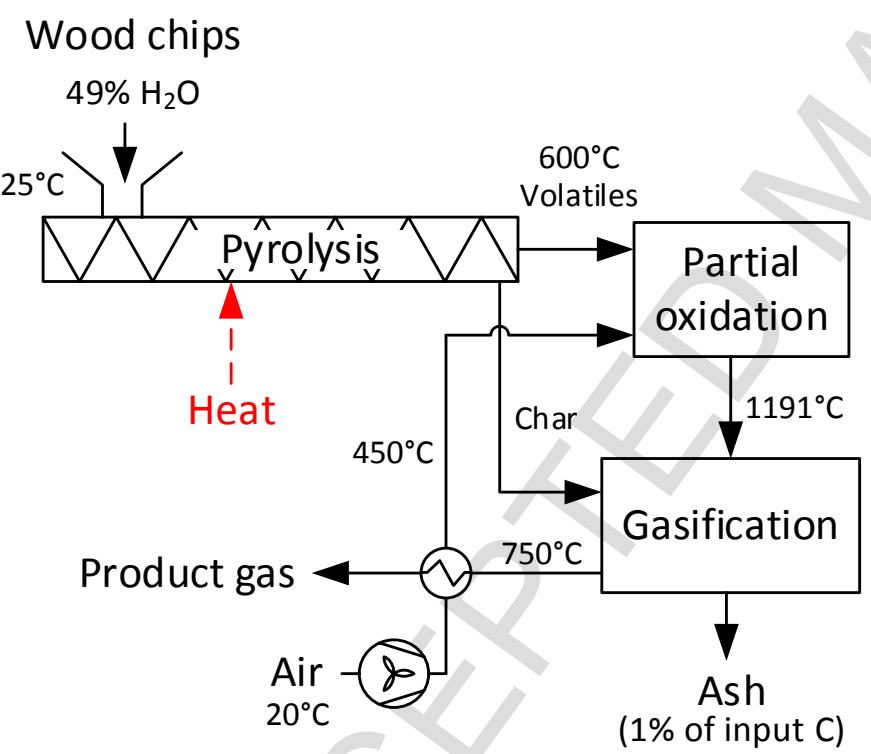

Figure 1 with resulting key data. Main model results including gas composition are compared to operational data for the TwoStage gasifier in Table 3 showing an overall satisfying fit. One of the key differences is the $\mathrm{CH}_{4}$ content that is negligible in the model, but in practice typically 1-2\% methane is formed in and/or slips by the partial oxidation zone, which converts most of it and other hydrocarbons. This difference will namely cause a slightly higher hydrogen content in the model as well as a slight difference in partial oxidation temperature due to endothermic reforming reactions. The POX (maximum) temperature is seen to be within range of the measured temperature, but this value will in practice fluctuate between $\approx 1100-1300^{\circ} \mathrm{C}$. 


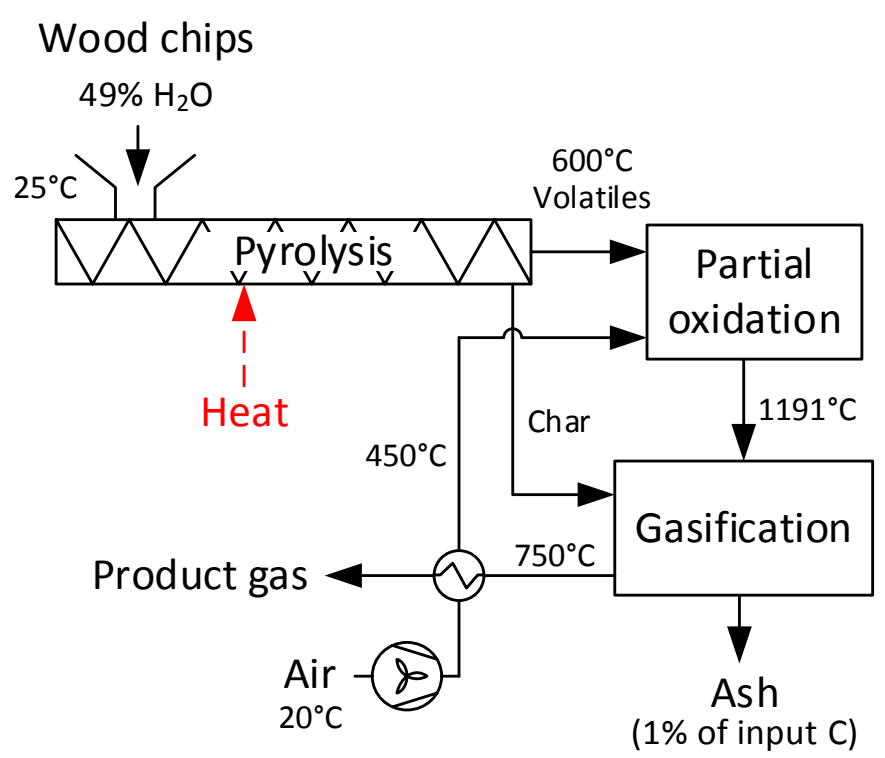

Figure 1 - Model of TwoStage gasifier

\begin{tabular}{lc|cc} 
& Unit & TwoStage Viking gasifier & Model \\
\hline Air/fuel flow & {$[\mathrm{kg} / \mathrm{kg}]$} & 1.36 & 1.33 \\
POX temperature & {$\left[{ }^{\circ} \mathrm{C}\right]$} & $1150 \pm 100$ & 1191 \\
Cold gas efficiency & {$[\%](\mathrm{LHV})$} & 90 & 89.1 \\
$\mathrm{H}_{2}$ & {$[\mathrm{v} \%]$} & 34 & 36 \\
$\mathrm{CO}$ & {$[\mathrm{v} \%]$} & 17 & 17 \\
$\mathrm{CO}_{2}$ & {$[\mathrm{v} \%]$} & 17 & 17 \\
$\mathrm{CH}_{4}$ & {$[\mathrm{v} \%]$} & 2 & 0 \\
$\mathrm{~N}_{2}$ & {$[\mathrm{v} \%]$} & 31 & 30 \\
$\mathrm{LHV}$ & {$[\mathrm{MJ} / \mathrm{kg}]$} & 6.6 & 6.4
\end{tabular}

Table 3 - Comparison of TwoStage gasifier [13] and model. All flows and fractions are dry.

The calibrated model is used to project various $\mathrm{O}_{2}-\mathrm{CO}_{2}$ mixtures, which are compared to the air-blown mode by implementing similar parameters. Two main weaknesses by using this direct comparison are namely that the $\mathrm{CH}_{4}$ concentration can be affected by a change in operation and that the product gas and air/ $\mathrm{O}_{2}-\mathrm{CO}_{2}$ temperatures are assumed constant across gasification media.

As seen in

Table 4 the direct substitution of $\mathrm{CO}_{2}$ for $\mathrm{N}_{2}$ with $21 \mathrm{v} \% \mathrm{O}_{2}$ will cause a decline in gasifier performance with lower temperatures and subsequent carbon conversion and efficiency. Namely the higher heat capacity is responsible for this decline, as the gasifier exhaust will have a higher content of sensible heat. In order to keep the efficiency and POX temperature at similar levels, a $\approx 12 \%$ larger volume flow is required. Generally it is seen that the efficiency and POX temperature are in the same range as for the air-blown mode. In line with the literature review, it is seen that an $\mathrm{O}_{2}$-concentration of $30 \mathrm{v} \%$ obtain very similar parameters to those of the air-blown mode. As an extreme case, pure oxygen might be added to the process, which is seen to obtain higher performance across parameters, as the otherwise large amounts of $\mathrm{N}_{2} / \mathrm{CO}_{2}$ does not need to be heated and carried through the system. Increasing the $\mathrm{O}_{2}$ concentration for higher cold gas efficiency is in line with experimental studies e.g. [20][26]. The use of pure oxygen on the plant might 
however be challenging with regards to the present plant design (temperatures, materials, gas flows etc.) and highly dependent on the fuel moisture levels in order to avoid hot spots. Therefore it is seen as reasonable to blend the oxygen with a carrier gas in order to make the system more robust and allow dryer fuels and potential other fuels with a lower volatile fraction that both will increase the POX temperature.

\begin{tabular}{lc|ccc|cc} 
& Unit & Air & $\mathrm{O}_{2}-\mathrm{CO}_{2}$ & $\mathrm{O}_{2}-\mathrm{CO}_{2}$ & $\mathrm{O}_{2}-\mathrm{CO}_{2}$ & $\mathrm{O}_{2}$ \\
\hline Oxygen fraction & {$[\mathrm{v} \%]$} & $\mathbf{2 1}$ & $\mathbf{2 1}$ & $\mathbf{2 1}$ & 30 & 100 \\
Gas/fuel flow & {$\left[\mathrm{m3}^{\mathrm{a} / \mathrm{kg}(\mathrm{dry})]}\right.$} & $\mathbf{1 . 1 3}$ & $\mathbf{1 . 1 3}$ & 1.26 & 0.80 & 0.22 \\
Gas preheat to $450^{\circ} \mathrm{C}$ & {$\left[\mathrm{kW}_{\text {th }}{ }^{\mathrm{b}}\right]$} & 2.6 & 3.6 & 4.0 & 2.6 & 0.5 \\
POX temperature & {$\left[{ }^{\circ} \mathrm{C}\right]$} & 1191 & 1085 & 1144 & 1197 & 1307 \\
Carbon conversion & {$[\%]$} & $\mathbf{9 9 . 0}$ & 90.2 & $\mathbf{9 9 . 0}$ & $\mathbf{9 9 . 0}$ & $\mathbf{9 9 . 0}$ \\
Cold gas efficiency & {$[\%](\mathrm{dry}, \mathrm{LHV})$} & 89.1 & 80.9 & 87.8 & 89.2 & 91.0 \\
\hline $\mathrm{H}_{2}$ & {$[\mathrm{v} \%(\mathrm{dry})]$} & 36 & 30 & 28 & 36 & 52 \\
$\mathrm{CO}$ & {$[\mathrm{v} \%(\mathrm{dry})]$} & 17 & 25 & 26 & 27 & 25 \\
$\mathrm{CO}_{2}$ & {$[\mathrm{v} \%(\mathrm{dry})]$} & 17 & 46 & 46 & 37 & 23 \\
$\mathrm{CH}_{4}$ & {$[\mathrm{v} \%(\mathrm{dry})]$} & 0 & 0 & 0 & 0 & 0 \\
$\mathrm{~N}_{2}$ & {$[\mathrm{v} \%(\mathrm{dry})]$} & 30 & 0 & 0 & 0 & 0 \\
$\mathrm{LHV}_{\text {mass }}$ & {$[\mathrm{MJ} / \mathrm{kg}]$} & 6.4 & 5.1 & 5.1 & 6.6 & 10.8 \\
$\mathrm{LHV}_{\text {vol }}$ & {$\left[\mathrm{MJ} / \mathrm{Nm}^{3}\right]$} & 5.8 & 6.1 & 6.1 & 7.0 & 8.5
\end{tabular}

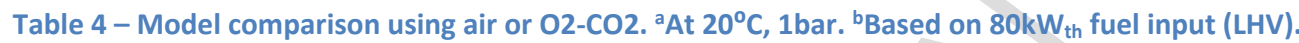

Based on the literature and modeling studies presented, the TwoStage Viking gasifier plant was modified and experimental campaigns were carried out over 3 days. The campaign details are presented in the following sections.

\section{Experimental methods and materials}

\subsection{The gasifier plant}

The TwoStage Viking gasifier has been developed for many years at the Biomass Gasification Group at the Technical University of Denmark. The $80 \mathrm{~kW}_{\text {th }}$ gasifier pilot plant processes wood chips in two stages: moving bed pyrolysis and downdraft fixed bed char gasification with a POX zone in between - see Figure 2 . The pyrolyzer employs an externally heated screw conveyer that processes the fuel up to $600^{\circ} \mathrm{C}$ by utilizing engine exhaust for heat supply. The released volatiles and char are led to the second reactor where they are exposed to a POX zone where $99 \%$ of the residual tar is converted [27]. The hot gases and char are then led to the char bed where the char is gasified and the remaining tars are reduced to a minimum by a 95$99 \%$ [27], resulting in a reported tar content of $\leq 0.1 \mathrm{mg} / \mathrm{nm}^{3}$ [12]. Coupled with a high carbon conversion of $99 \%$, the cold gas efficiency reaches $87 \%$ on dry basis and $93 \%$ on wet basis (34wt\% moisture) [12]. The gasifier applies only a simple bag filter for gas cleaning in order to capture particles and a condenser to dry the product gas. 


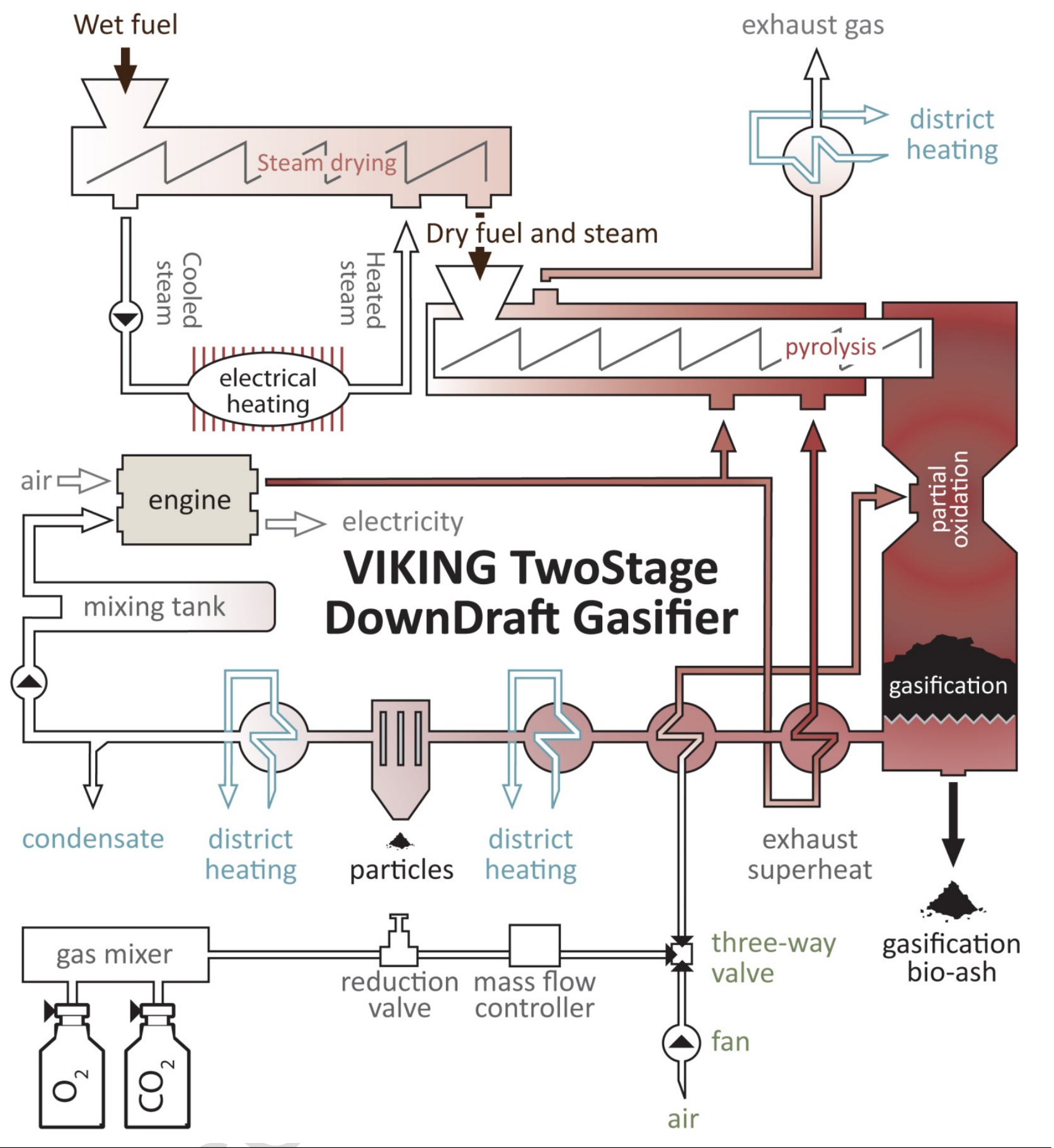

Figure 2 - Schematic overview of the Viking gasifier with an installed steam dryer and $\mathrm{O}_{2}-\mathrm{CO}_{2}$ mixing setup.

As part of the development of the system, a steam dryer has been installed on the Viking plant. This will enable the use of fuel with high moisture contents up to $\approx 60-70 \%$ and also enable separation of the hightemperature pyrolysis heat exchanger area as shown in scaled up designs [28]. The steam dryer utilizes a steam loop, where it is moved and heated by a blower and an electrical heater. As seen on Figure 2, the steam is then passed through a screw conveyer where the fuel moisture evaporates. The main fraction of the steam is then recirculated via a blower and reheated, while the produced moisture-steam is carried with the dry fuel to the pyrolyzer. The inlet steam temperature to the steam dryer was $173^{\circ} \mathrm{C}$. 
The standard gasification medium is atmospheric air that is delivered to the system via a blower. Replacing the air injection with an $\mathrm{O}_{2}-\mathrm{CO}_{2}$ mixture is done via the following setup. The $\mathrm{O}_{2}$ and $\mathrm{CO}_{2}$ are supplied via gas bottles, reduced to 10 bar via reduction valves and led to a gas mixer (Dansensor MAP Mix Provectus.) The gas mixer is based on two mass flow controllers, which secure the correct composition within $1 \%$. The mixer feeds a $100 \mathrm{~L}$ buffer tank with a reduction valve, that secures a stable outlet pressure at $3 \mathrm{bar}$. The system feeds a thermal mass flow controller (Aalborg Model GFC) that uses the original air blower signal from the PLC (Siemens Step7) to dose the mixture near atmospheric pressure levels. The flow controller has an accuracy of $\pm 1 \%$. The mixture composition is manually set at the mixer and has been thoroughly tested beforehand. The equipment is shown in Figure 3.
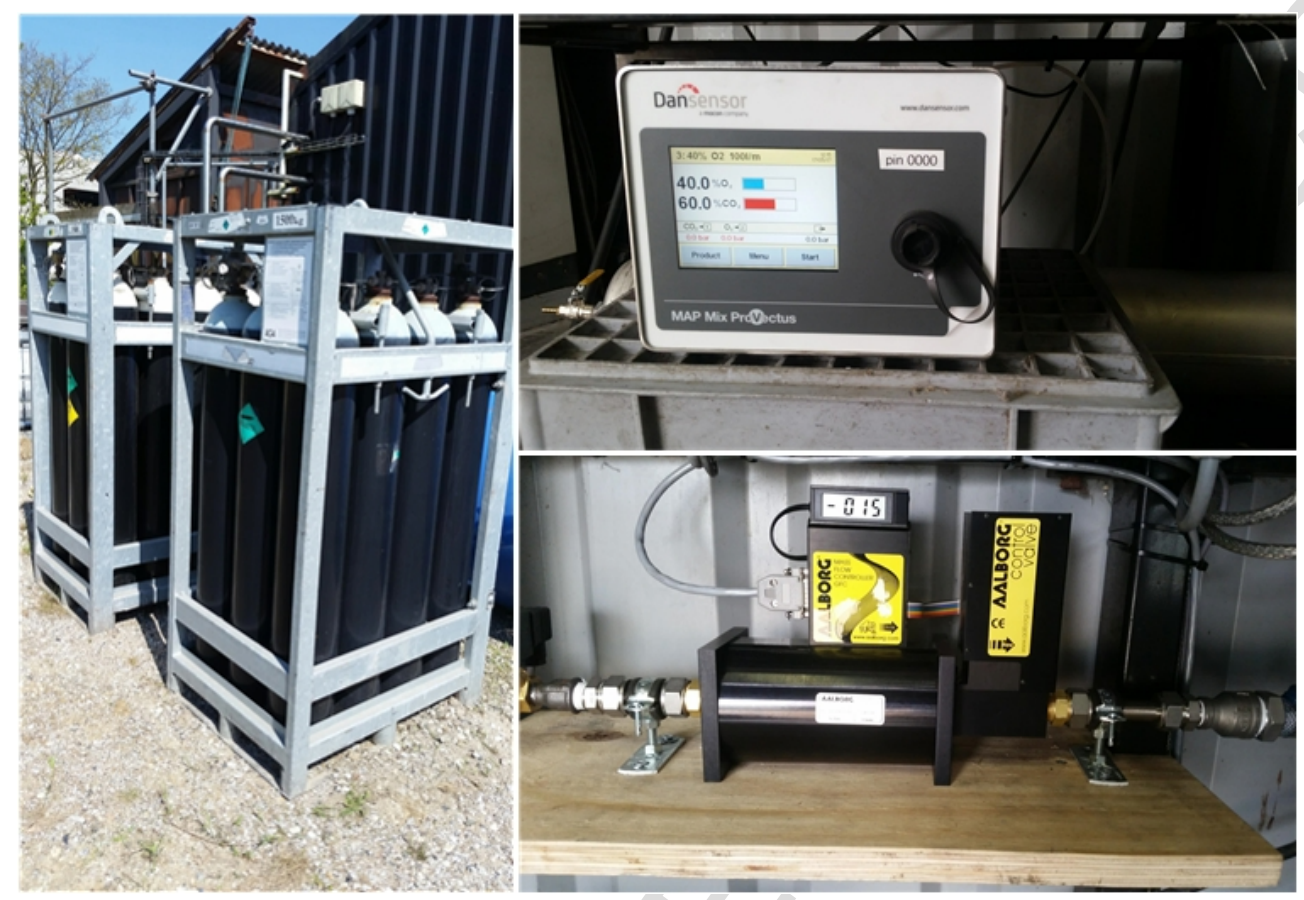

Figure 3 - Experimental setup for converting the air-blown gasifier to $\mathrm{O}_{2}-\mathrm{CO}_{2}$-blown. Left: Gas bottles. Upper right: gas mixer. Lower right: mass flow controller.

The gasifier can be operated via various strategies, but a constant air/ $\mathrm{O}_{2}-\mathrm{CO}_{2}$ flow into the POX zone is chosen as the primary setpoint. The fuel feed is automatically set to maintain a bed height within a specified interval. The ash is discharged by the grate as the pressure difference builds up. When switching to the $21 \mathrm{v} \%$ oxygen-mix, the volume flow is maintained similar to air. The $25 \mathrm{v} \%$ oxygen-mix volume flow is set to match the absolute oxygen flow, meaning a smaller total gas flow is applied.

\subsection{Fuel analysis}

Standard Danish spruce wood chips were used as fuel for the gasifier. The main fuel elements $(C, H, N, S, O)$ was analyzed with the VarioEL III (Elementar Analysensysteme $\mathrm{GmbH}$, Germany) and results are shown in Table 5. The inorganic elements were measured by inductively coupled plasma optical emission spectrometry (ICP-OES) analysis and are shown in Table 6. The analysis showed a high amount of Ca (1063.0 and $1061.9 \mu \mathrm{g} / \mathrm{g}$ ), whereas the presence of $\mathrm{K}, \mathrm{Mg}$ and $\mathrm{Na}$ were also significant in the fuel.

\begin{tabular}{|c|c|c|c|c|c|}
\hline & $\mathbf{C}$ & $\mathbf{H}$ & $\mathbf{N}$ & $\mathbf{S}$ & $\mathbf{O}$ (rest) \\
\hline & {$[\%]$} & {$[\%]$} & {$[\%]$} & {$[\%]$} & {$[\%]$} \\
\hline
\end{tabular}




\begin{tabular}{|l|l|l|l|l|l|}
\hline Average & 53.8 & 4.9 & 0.1 & 0.1 & 41.2 \\
\hline
\end{tabular}

Table 5 - Composition of dry spruce wood chips used in the experiments based on 4 samples.

\begin{tabular}{|l|c|c|c|c|c|c|c|c|c|c|c|c|}
\hline Element & Al & B & Ca & Cu & Fe & K & Mg & Mn & Na & P & S & Zn \\
\hline Sample \#1 & 38.6 & 1.6 & 1063.0 & 1.2 & 38.4 & 295.0 & 116.5 & 8.2 & 112.2 & 76.2 & 130.3 & 8.7 \\
\hline Sample \#2 & 36.9 & 1.3 & 1061.9 & 1.5 & 36.2 & 262.1 & 113.8 & 8.0 & 109.3 & 77.2 & 125.5 & 8.5 \\
\hline
\end{tabular}

Table 6 - Inorganic elements detected in the wood chips $[\mu \mathrm{g} / \mathrm{g}]_{\mathrm{dry}}$

The moisture content was relatively low compared to previous tests and was measured to $16-17 \mathrm{wt} \%$ on 4 occasions during testing, by weighing samples before and after at least 24 hours residence in a $105^{\circ} \mathrm{C}$ oven.

\subsection{Gas analysis}

Several types of analyses were performed on the collected product gas. For tar measurements, solid phase adsorption (SPA) was used. Sulphur was measured via gas samples and gas chromatography. For gas composition measurements, both gas chromatography from pipettes and online measurements were used, because the gas composition were out of the online equipment measurement range when applying $\mathrm{O}_{2}-\mathrm{CO}_{2}$.

\section{Solid phase adsorption (SPA)}

The tar measurements were taken at two locations: before the bag filter and after the condenser. Sampling was done through a needle connected to the filter and subsequently a $100 \mathrm{ml}$ syringe - see Figure 4 . The needle was placed in the middle of the hot gas flow as the samples were taken. Sample was done over approximately 30 seconds.

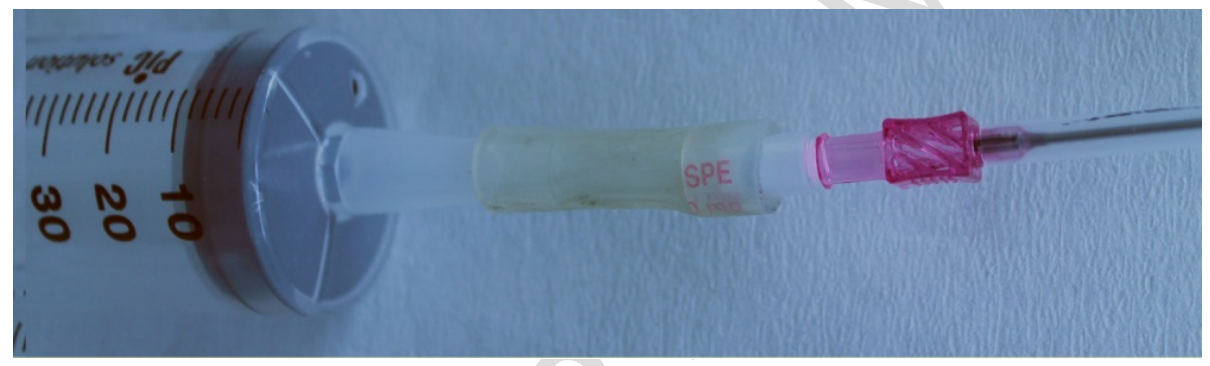

Figure 4 -SPA sampling: needle with cartridge fastened to syringe via rubber band

The received SPA filters were removed, extracted and resulting samples were analyzed by gas chromatography - mass spectrometry (GC-MS). The cartridges were removed from the SPE tubes and were stored overnight after addition of $10 \mathrm{ml}$ acetone, $1 \mathrm{ml}$ phenol D5 and $1 \mathrm{ml}$ polycyclic aromatic hydrocarbon (PAH) standard mixture. (The PAH standard mixture included: naphthalene D8, acenaphthene D10, anthracene D10, phenanthrene D10, fluorene D10, pyrene D10). Theacetone was then evaporated and the samples were redissolved in $1 \mathrm{ml}$ acetone. The samples were analyzed by GC-MS using a Hewlett Packard HP 6890 gas chromatograph interfaced to a HP5973 Mass Selective Detector (Agilent, Denmark). Samples $(1 \mu \mathrm{l})$ were injected in split mode (1:20) using an HP 7683 autosampler (Agilent, Denmark). The source and rod temperatures were $230^{\circ} \mathrm{C}$ and $150^{\circ} \mathrm{C}$, respectively. The products were separated using a $0.32-\mathrm{mm}$ i.d. $\times 30 \mathrm{~m}$ WCOT-fused silica column coated with VF-23ms at a thickness of $0.25 \mu \mathrm{m}$ (Analytical Instruments as, Denmark). The carrier gas was He at a flow rate of $1.2 \mathrm{ml} / \mathrm{min}$. Separation of products was achieved using a temperature program from 70 to $250^{\circ} \mathrm{C}$ at $10^{\circ} \mathrm{C} / \mathrm{min}$. The applied ionization energy was $70 \mathrm{eV}$. Full 
mass spectra were recorded every $0.3 \mathrm{~s}$ (mass range $\mathrm{m} / \mathrm{z} 40-450$ ). Products were identified using NIST search engine version $2.0 \mathrm{f}$. (Agilent, Denmark). The deuterated stable isotopes were used as internal standards and used for quantification, as they were added to the system in a known amount.

\section{Sulphur measurements}

Gas sampling for analysing the sulphur components $\mathrm{H}_{2} \mathrm{~S}$ and $\mathrm{COS}$ were performed Day 1 (air blown gasifier operation) and Day 3 ( $25 \mathrm{v} \%$ oxygen blown gasifier operation). Both days sampling were performed upstream (before particle filter) and downstream (after the condenser) of the gasifier gas cleaning equipment. Three samples were taken at each location comprising a total number of six samples each of the two days. The gas samples were extracted into dedicated 5 litre Supel ${ }^{\mathrm{TM}}$ Inert Foil gas sampling bags with screw cap valves from SUPELCO. Upstream gas cleaning the product gas pressure was negative and an EX gas pump was used to extract the gas into the SUPELCO bags. Downstream gas cleaning the product gas pressure was positive and large enough to fill the sampling bags by just opening the sampling port valve. Prior to the sampling the sampling connection tubes were flushed to get rid of air and accumulated condensed water in the sampling ports.

The sampling on Day 1 was performed as described above, but the subsequently analysis revealed sensitivity issues using the Agilent GCMS due the high water content in the gas samples. Therefore it was decided to add an amount of helium (He) to the gas sampling bags before performing the actual measurements at October 12 . The result was diluted gas samples with water dew point lower than $100 \%$ (unsaturated gas samples) which caused lesser issues during analysis.

Analysis was done with an Agilent 7890A gas chromatograph combined with 5975C mass selective detector. Pre-concentration of the sample was done with a Markes Unity 2 thermal desorber with air sampler. Pre-concentration conditions: Markes T6SUL-2S cold trap at $-30^{\circ} \mathrm{C}$; gas flow $50 \mathrm{ml} / \mathrm{min}$ during 5 minutes. Injection: trap heating at maximum rate to $300^{\circ} \mathrm{C}$; total split ratio 29.4. Analysis: separation of $\mathrm{H}_{2} \mathrm{~S}$ and COS was done at an Agilent DB-5ms column ( $20 \mathrm{~m} \times 180 \mathrm{~mm} \times 0,14 \mathrm{~mm}$ ) at $35^{\circ} \mathrm{C}$ with He as carrier gas. Other components were removed from the column by heating to $200^{\circ} \mathrm{C}$ at $25^{\circ} \mathrm{C} / \mathrm{min}$.

\section{Gas analysis from gas pipettes}

The gas sampling was done after the product gas condenser, where the pipettes were connected to the sampling port with a rubber tube - see Figure 5 . The vessel was flushed thoroughly for roughly 1 minute by opening both ends and afterwards filled. Gas analysis was carried out within 1-2 hours to avoid leakage of $\mathrm{H}_{2}$.

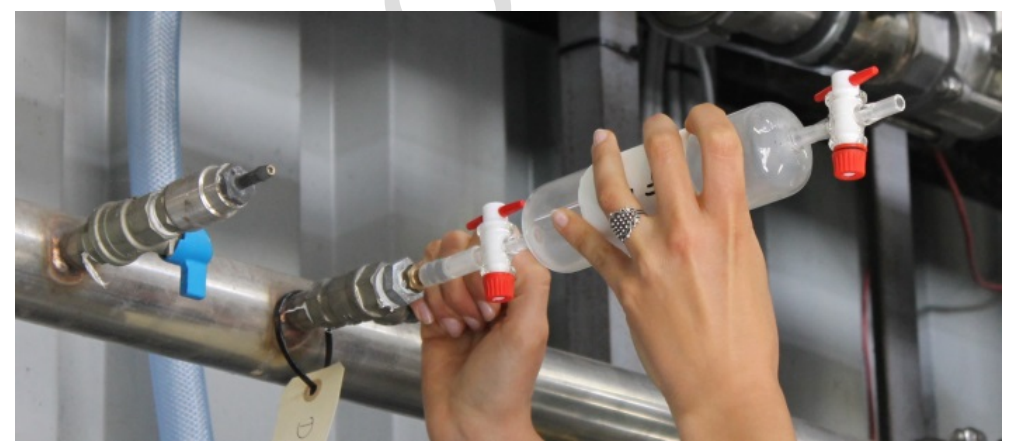

Figure 5 - Gas pipette sampling with rubber tube connection to sampling port 
The samples were analyzed by an Agilent Technologies 7890A gas chromatograph (Agilent, Denmark). Samples (volumes 100-1000 $\mu$ l) were injected in split mode (1:25) using Pressure-Lok ${ }^{\circledR}$ Syringes (Vici, Baton Rouge, USA). For measurements of $\mathrm{H}_{2}, \mathrm{CO}$ and $\mathrm{CH}_{4}$, the gas components were separated using a 0.32-mm i.d. $\times 25 \mathrm{~m}$ PLOT-fused silica column coated with Molsieve 5A (Analytical Instruments as, Denmark). The carrier gas was $\mathrm{Ar}$ at a flow rate of $1 \mathrm{ml} / \mathrm{min}$. For $\mathrm{CO}$ measurements, He carrier gas was used. Separation of products was achieved using a temperature program from 50 to $235^{\circ} \mathrm{C}$ at $10^{\circ} \mathrm{C} / \mathrm{min}$. For measurements of $\mathrm{CO}_{2}$, the gas components were separated using a $0.32-\mathrm{mm}$ i.d. $\times 25 \mathrm{~m}$ PLOT-fused silica column coated with Poraplot U(Analytical Instruments as, Denmark). The carrier gas was He at a flow rate of $1 \mathrm{ml} / \mathrm{min}$. Separation of products was achieved using a temperature program from 75 to $235^{\circ} \mathrm{C}$ at $16^{\circ} \mathrm{C} / \mathrm{min}$. Gas components were detected with a thermal conductivity detector (TCD).

\section{Online gas measurements}

On dry and tar-free basis, the gas composition were measured by an Advance Optima 2020 Modular continuous process gas analyzer system. The system was equipped with a Caldos 15 cell for analysis of $\mathrm{H}_{2}$ and an Uras 14 cell for $\mathrm{CO}, \mathrm{CO}_{2}$ and $\mathrm{CH}_{4}$ (ABB). The only issue with the Uras 14 cell was that the $\mathrm{CO}_{2}$ measurement range is $30 \%$, which makes the gas composition data unprecise above this limit. An PMA 10 $\mathrm{O}_{2}$-analzer were also applied. $\mathrm{N}_{2}$ was calculated as difference. All of the equipment has a $\pm 1 \%$ unvertainty range.

\section{Experimental results}

The gasifier was heated up to stable operating conditions over roughly 24 hours using initially gas burners and afterwards air-blown operation from afternoon till next morning. The reported tests were carried out over 3 following days: Day 1 - air-blown, Day $2-21$ and $25 \mathrm{v} \% \mathrm{O}_{2}-\mathrm{CO}_{2}$-blown, Day $3-21 \mathrm{v} \% \mathrm{O}_{2}-\mathrm{CO}_{2}$-blown. While tests were run during work hours, the system was kept thermally stable by operating it fully automated and unmanned overnight with air.

\subsection{Operating temperatures and gas composition}

Time dependent temperature data for air and $\mathrm{O}_{2}-\mathrm{CO}_{2}$ operation is shown in Figure 6 and Figure 7 respectively, while the corresponding online gas measurements are given in Figure 8 and

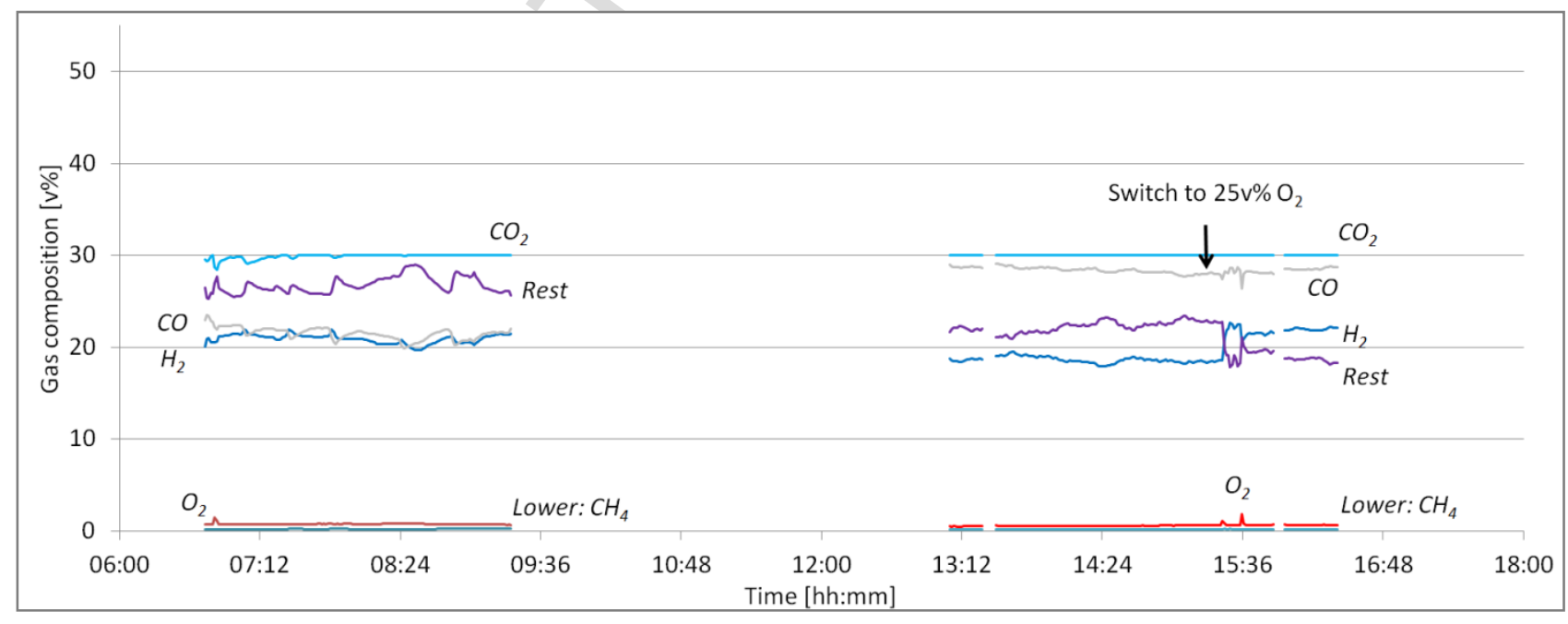

Figure 9. Temperature measurements were taken after the air preheater, at the POX zone, just above the gasifier grate and at the reactor outlet and all parameters showed satisfying process stability. In- and 
decreasing trends can be due to changes in fuel moisture and/or thermal stability. The operating data is within range of previous tests with the gasifier [12][13][25].

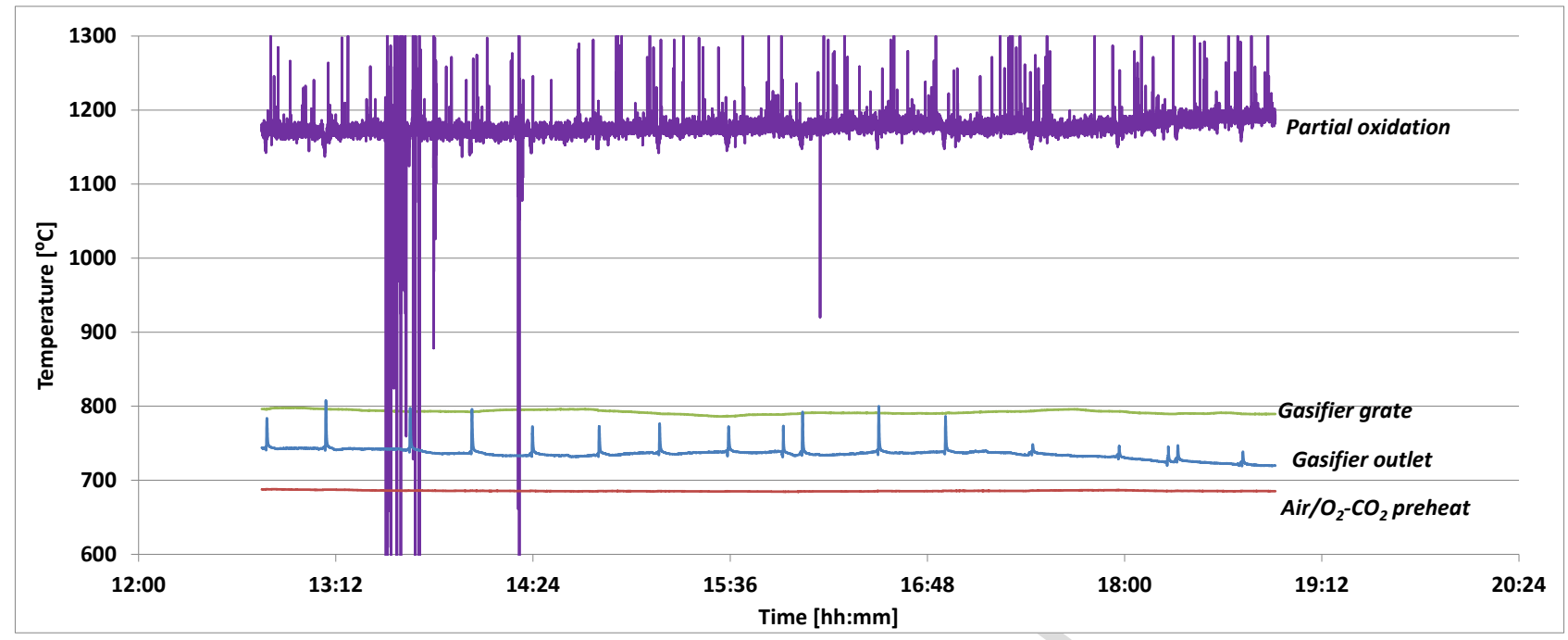

Figure 6 - Operating temperatures for air-blown operation during Day 1.

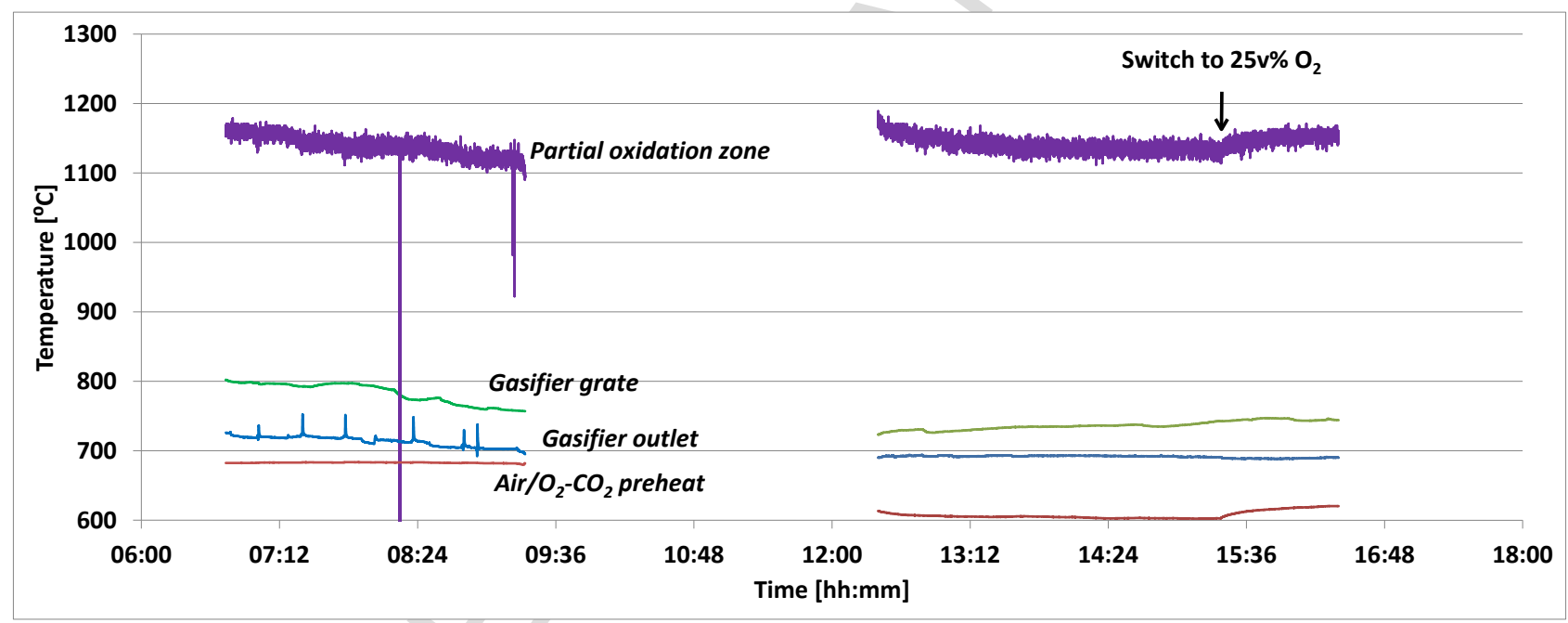

Figure 7 - Operating temperatures for $21 \mathrm{v} \%$ and $25 \mathrm{v} \% \mathrm{O}_{2}-\mathrm{CO}_{2}$-blown operation during the time of testing. The two periods before the switch to $25 \mathrm{v} \% \mathrm{O}_{2}-\mathrm{CO}_{2}$ is $21 \mathrm{v} \% \mathrm{O}_{2}-\mathrm{CO}_{2}$. Day 2 


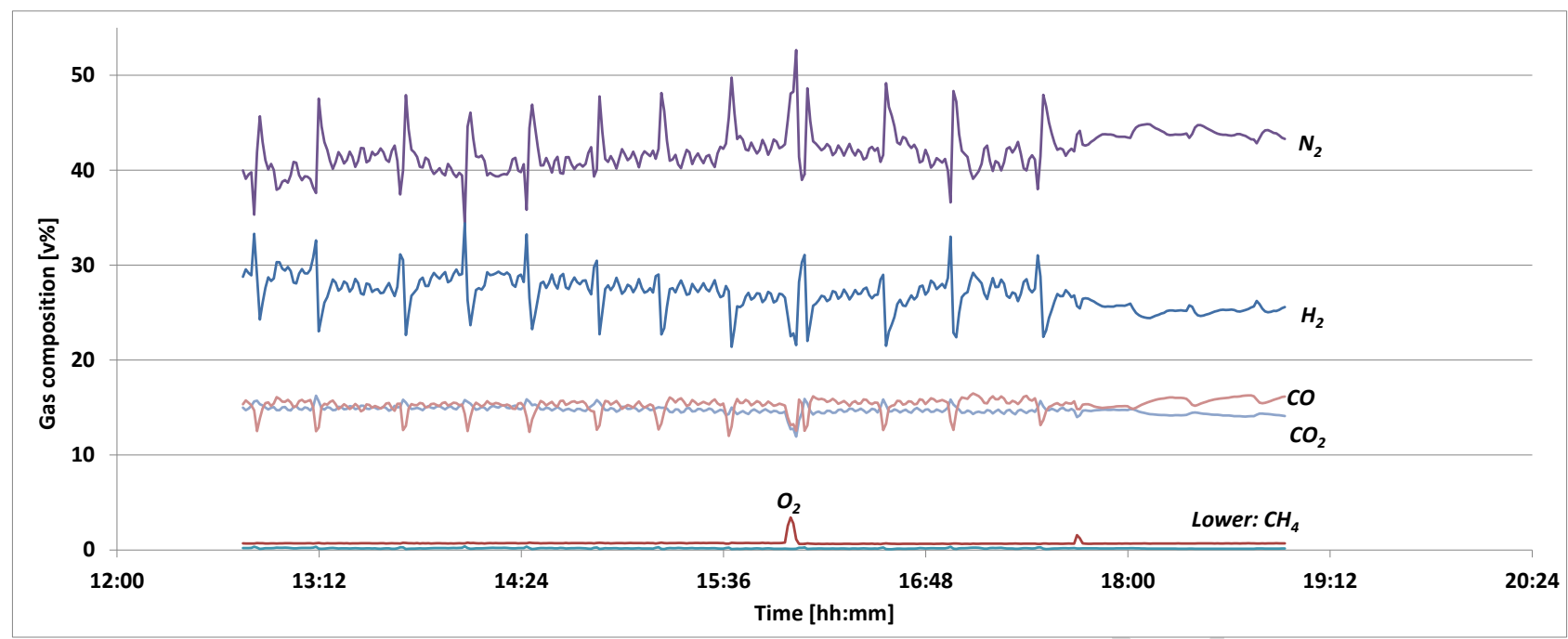

Figure 8-Gas composition for air-blown operation during Day 1. The spikes of $\mathrm{N}_{2}$ are caused by filter flushing and these are minimized around 17:30 where the gas analysis is taken after the product gas buffer tank instead of before.

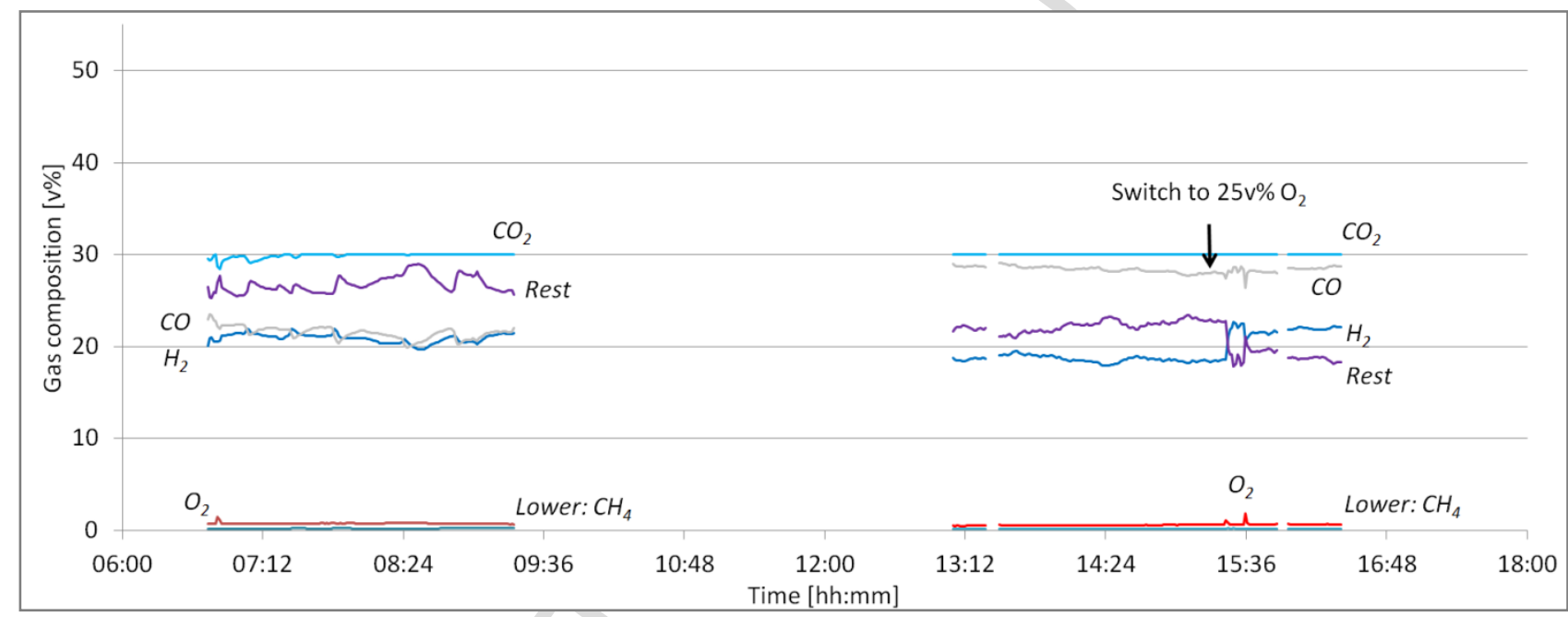

Figure 9 - Gas composition for $21 \mathrm{v} \%$ and $25 \mathrm{v} \% \mathrm{O}_{2}-\mathrm{CO}_{2}$-blown operation during Day 2. Test were interrupted by a power outage around 9:20.Note that the measurements are out the measurement range and therefore not precise.

The operating temperatures and gas compositions are summarized as averages in Table 7 and gas pipette gas compositions are given in Table 8. As discussed in the modeling study (Section 2), it is seen that the general trend is that the temperatures are decreasing in the gasifier as the process is switched from air to $21 \mathrm{v} \% \mathrm{O}_{2}-\mathrm{CO}_{2}$ : a POX temperature reduction of $52-69^{\circ} \mathrm{C}$ with grate temperatures decreasing with $31-36^{\circ} \mathrm{C}$. The preheating temperature is generally somewhat lower, which is expected as the heat capacity is significantly higher compared to air. At $25 \mathrm{v} \%$ oxygen, both preheat, POX and grate temperatures are increased and are more similar to air-blown data.

The $\mathrm{N}_{2}$ content is drastically reduced, but a couple of percentages remain, which is mainly due to fuel feed ash silo $\mathrm{N}_{2}$ purging. The level is expected to be reduced to a negligible content if e.g. $\mathrm{CO}_{2}$-purge is applied instead. As expected from the modeling, the $\mathrm{H}_{2}$ content is slightly lower, which is likely a result of a displacement in the water-gas shift reaction as the $\mathrm{CO}_{2}$ concentration is much higher. The $\mathrm{CO}_{2}$ and $\mathrm{CO}$ concentrations are in line with the predictions of the model, but slightly lower though. This small difference 
can - amongst several minor differences - be partly attributed to a lower steam content (model fuel moisture $49 \%$, while $16-17 \%$ experimentally) content that will promote $\mathrm{CO}_{2}$ conversion in the char bed. As mentioned, the oxygen flow is constant across tests, meaning that the $\mathrm{CO}_{2}$ will be lower at $25 \mathrm{v} \% \mathrm{O}_{2}$, which is the main cause of the lower $\mathrm{CO}_{2}$ concentration at this condition. The lower $\mathrm{CO}$ level at $25 \mathrm{v} \% \mathrm{O}_{2}-\mathrm{CO}_{2}$ is likely due to reduced char- $\mathrm{CO}_{2}$ gasification reactions. Methane contents are low and similar for both tests as the POX temperature remains high.

The samples during the $25 \mathrm{v} \% \mathrm{O}_{2}-\mathrm{CO}_{2}$ operation is seen to be somewhat inaccurate, as the sum of gas components did not close in on $100 \%$ and it is still unknown why this is the case.

\begin{tabular}{|c|c|c|c|c|c|}
\hline $\begin{array}{l}\text { Test } \\
\text { Time period }\end{array}$ & Day & $\begin{array}{c}\mathrm{T}_{\text {preheat }} \\
{\left[{ }^{\circ} \mathrm{C}\right]} \\
\end{array}$ & $\begin{array}{l}\mathrm{T}_{\mathrm{POX}} \\
{\left[{ }^{\circ} \mathrm{C}\right]} \\
\end{array}$ & $\begin{array}{l}\text { grate } \\
{\left[{ }^{\circ} \mathrm{C}\right]} \\
\end{array}$ & $\begin{array}{c}\mathrm{T}_{\text {outlet }} \\
{\left[{ }^{\circ} \mathrm{C}\right]} \\
\end{array}$ \\
\hline $\begin{array}{l}\text { Air } \\
12: 45-18: 45\end{array}$ & 1 & 686 & 1177 & 792 & 736 \\
\hline $\begin{array}{l}\text { Air \#2 } \\
0: 00-6: 13\end{array}$ & 2 & 680 & 1188 & 766 & 719 \\
\hline $\begin{array}{l}21 \mathrm{v} \% \mathrm{O}_{2}-\mathrm{CO}_{2} \\
6: 44-9: 20\end{array}$ & 2 & 683 & 1137 & 730 & 714 \\
\hline $\begin{array}{l}21 \mathrm{v} \% \mathrm{O}_{2}-\mathrm{CO}_{2} \\
13: 05-15: 24\end{array}$ & 2 & 604 & 1136 & 735 & 692 \\
\hline $\begin{array}{l}25 \mathrm{v} \% \mathrm{O}_{2}-\mathrm{CO}_{2} \\
15: 24-16: 24\end{array}$ & 2 & 616 & 1149 & 745 & 689 \\
\hline $\begin{array}{l}\text { Air \#3 } \\
0: 00-6: 23\end{array}$ & 3 & 640 & 1183 & 766 & 695 \\
\hline $\begin{array}{l}21 v \% \mathrm{O}_{2}-\mathrm{CO}_{2} \\
10: 42-17: 00\end{array}$ & 3 & 595 & 1114 & 1 & 708 \\
\hline
\end{tabular}

Table 7 - Day-by-day Averaged temperature and online gas data for the test campaigns. ${ }^{\text {aTest }}$ data for overnight operation without gas analysis.

\begin{tabular}{|l|c|c|c|c|c|c|c|}
\hline & Day - time & $\begin{array}{c}\mathbf{H}_{\mathbf{2}} \\
{[\mathbf{v} \%]}\end{array}$ & $\begin{array}{c}\mathbf{C O}_{\mathbf{2}} \\
{[\mathbf{v} \%]}\end{array}$ & $\begin{array}{c}\mathbf{C O} \\
{[\mathbf{v} \%]}\end{array}$ & $\begin{array}{c}\mathbf{C H}_{4} \\
{[\mathbf{v} \%]}\end{array}$ & $\begin{array}{c}\mathbf{N}_{\mathbf{2}} \\
{[\mathbf{v} \%]}\end{array}$ & SUM \\
\hline Air & $\begin{array}{c}1- \\
12: 45-18: 45\end{array}$ & 27.0 & 14.7 & 15.3 & 0.4 & 42.1 & 99.5 \\
\hline \multirow{2}{*}{$21 \mathrm{v} \%$} & $2-11: 15$ & 24.0 & 42.6 & 26.9 & 0.05 & 4.6 & 98.2 \\
\cline { 2 - 8 } $\mathrm{O}_{2}-\mathrm{CO}_{2}$ & $2-13: 20$ & 21.2 & 43.2 & 24.9 & 0.16 & 4.7 & 94.2 \\
\cline { 2 - 8 } & $2-13: 22$ & 20.6 & 44.3 & 25.8 & 0.22 & 4.6 & 95.5 \\
\hline $25 \mathrm{v}^{2}$ & $2-15: 50$ & 21.2 & 39.3 & 18.6 & 0.04 & 3.8 & 82.9 \\
$\mathrm{O}_{2}-\mathrm{CO}_{2}$ & $2-16: 50$ & 22.8 & 39.4 & 20.6 & 0.09 & 4.6 & 87.5 \\
\hline
\end{tabular}

Table 8 - Data from online gas analysis (air) and gas chromatography data from gas pipette samples (21v\% and $25 \mathrm{v} \% \mathrm{O}_{2}$-in- $\mathrm{CO}_{2}$ ).

\subsection{Tars and inorganics}

Tar measurements are shown in Table 9. For air-blown operation, the results show expected low results in the low $\mathrm{mg} / \mathrm{m}^{3}$-range with only PAH compounds present. The particle filter is seen to not cause any significant reduction in tar concentration, however on day 1 no tars could be measured after the filter. While the relative difference between tar concentrations in the air and $\mathrm{O}_{2}-\mathrm{CO}_{2}$ samples is high, the absolute 
difference is seen to be very small. Hence no significant difference is seen between the two states. It is however interesting to provide a brief overview of the parameters that could cause a difference (char bed height and product gas flows were seen to be similar across the samples and are not expected to impact the tar):

- Reduced grate and POX temperature with $\mathrm{O}_{2}-\mathrm{CO}_{2}$ of $\approx 60^{\circ} \mathrm{C}$ and $\approx 40^{\circ} \mathrm{C}$ respectively will decrease tar conversion, as the conversion by thermal and chemical (char) means will be reduced.

- Applying a $\mathrm{CO}_{2}$-rich gasification medium will affect the char structure, as it has shown to produce char with a larger microstructure, specifically increase micro- and mesopore area e.g. [29], which will likely increase tar conversion [29][30]

- By increasing the $\mathrm{CO}_{2}$ partial pressure, it is likely that an increase in dry reforming of tar over the char will be present and hence decrease the tar concentration.

\begin{tabular}{|c|c|c|c|c|c|c|}
\hline Time & Location & $\begin{array}{l}\text { Gasifier } \\
\text { medium }\end{array}$ & Pyrene & Naphthalene & $\underset{\left[\mathrm{mg} / \mathrm{Nm}^{3}\right]}{\text { Sum }}$ & $\begin{array}{c}\text { Sum } \\
{[\mathrm{ppm}]}\end{array}$ \\
\hline Pre-liminary & $\begin{array}{l}\text { Before } \\
\text { filter }\end{array}$ & Air & $4.9 \pm 0.2$ & 0 & 4.9 & N/A \\
\hline Pre-liminary & $\begin{array}{l}\text { After } \\
\text { filter }\end{array}$ & Air & $4.2 \pm 0.5$ & 0 & 4.2 & N/A \\
\hline $\begin{array}{l}\text { 10:29 } \\
\text { Day } 1\end{array}$ & $\begin{array}{l}\text { Before } \\
\text { filter }\end{array}$ & Air & 2.8 & 0 & 2.8 & 0.003 \\
\hline $\begin{array}{l}\text { 11:00 } \\
\text { Day } 1\end{array}$ & $\begin{array}{l}\text { Before } \\
\text { filter }\end{array}$ & Air & 3 & 0 & 3 & 0.003 \\
\hline $\begin{array}{l}\text { 10:05 } \\
\text { Day } 1\end{array}$ & $\begin{array}{l}\text { After } \\
\text { filter }\end{array}$ & Air & 0 & 0 & 0 & 0 \\
\hline $\begin{array}{l}\text { 10:17 } \\
\text { Day } 1\end{array}$ & $\begin{array}{l}\text { After } \\
\text { filter }\end{array}$ & Air & 0 & 0 & 0 & 0 \\
\hline Preliminary & $\begin{array}{l}\text { Before } \\
\text { filter }\end{array}$ & $\begin{array}{c}21 \mathrm{v} \% \\
\mathrm{O}_{2}-\mathrm{CO}_{2}\end{array}$ & $5.7 \pm 0.8$ & $3.5 \pm 2.5$ & 9.2 & N/A \\
\hline Preliminary & $\begin{array}{l}\text { After } \\
\text { filter }\end{array}$ & $\begin{array}{c}21 \mathrm{v} \% \\
\mathrm{O}_{2}-\mathrm{CO}_{2}\end{array}$ & $3.8 \pm 0.2$ & $6.5 \pm 0.4$ & 10.3 & N/A \\
\hline $\begin{array}{l}13: 53 \\
\text { Day } 2\end{array}$ & $\begin{array}{l}\text { Before } \\
\text { filter }\end{array}$ & $\begin{array}{c}21 \mathrm{v} \% \\
\mathrm{O}_{2}-\mathrm{CO}_{2}\end{array}$ & 0 & 0 & 0 & 0 \\
\hline $\begin{array}{l}13: 42 \\
\text { Day } 2\end{array}$ & $\begin{array}{l}\text { After } \\
\text { filter }\end{array}$ & $\begin{array}{l}21 \mathrm{v} \% \\
\mathrm{O}_{2}-\mathrm{CO}_{2}\end{array}$ & 1 & 0 & 1 & 0.001 \\
\hline $\begin{array}{l}13: 47 \\
\text { Day } 2\end{array}$ & $\begin{array}{l}\text { After } \\
\text { filter }\end{array}$ & $\begin{array}{c}21 \mathrm{v} \% \\
\mathrm{O}_{2}-\mathrm{CO}_{2}\end{array}$ & 0 & 0 & 0 & 0 \\
\hline
\end{tabular}

Table 9 - Tar measurements $\left[\mathrm{mg} / \mathrm{Nm}^{3}\right]$ before and after the bag filter of the gasifier. Preliminary samples were taken during the initial tests of the system $\mathbf{2}$ months prior to the main experimental work that is reported here - operation conditions were very similar.

Gas samples were taken during Day 1 and 3 to assess the sulphur load and results are shown in Table 10. The range of 0.6-2.8 ppm total sulphur is within previous measurements of the gasifier of $3.7 \mathrm{ppm}$ of COS (no $\mathrm{H}_{2} \mathrm{~S}$ ) [25], 0.17-0.28 ppm of $\mathrm{COS}\left(\mathrm{no}_{2} \mathrm{~S}\right)$ [32] and <2ppm $\mathrm{H}_{2} \mathrm{~S}+\mathrm{COS}$ [33], which is also in line with the sulphur content of the applied wood fuels (Table 6) and is similar to previous analysis of wood fuel for the Viking [12]. It was expected that the bag filter might capture some of the sulphur species, as it will be partially coated with char from the gasifier and hence act as a carbon filter. It is however seen that this is not the case, as the filters' capture, if any, is negligible. The sampling and analysis were carried out by 
Danish Gas Technology Center and the relative uncertainty was estimated based on experiences to $40 \%$ for the first three samples in Table 10 and $25 \%$ for the remaining samples.

Between the media, the difference in sulphur species is negligible, with an additional 1ppm extra on average for the $\mathrm{O}_{2}-\mathrm{CO}_{2}$ blend. This is due to additional COS, that could be slightly promoted with the given gas composition. As mentioned, previous tests have shown higher COS levels when air was applied, and hence the difference might also be due to small variations in operation from Day 1 to 3 .

\begin{tabular}{|c|c|c|c|c|c|}
\hline Samplingtime & Location & $\begin{array}{c}\text { Gasification } \\
\text { media }\end{array}$ & $\begin{array}{c}\mathrm{H}_{2} \mathrm{~S} \\
{[\mathrm{ppm}]}\end{array}$ & $\begin{array}{c}\text { COS } \\
{[\mathrm{ppm}]}\end{array}$ & $\begin{array}{l}\text { Total S } \\
\text { [ppm] }\end{array}$ \\
\hline $\begin{array}{l}\text { Day } 1 \\
12: 20\end{array}$ & Before filter & Air & 0.1 & 0.6 & 0.7 \\
\hline $\begin{array}{l}\text { Day } 1 \\
12: 23\end{array}$ & After filter & Air & 0.1 & 0.5 & 0.6 \\
\hline $\begin{array}{l}\text { Day } 1 \\
12: 27\end{array}$ & Before filter & Air & 0.1 & 1.0 & 1.1 \\
\hline $\begin{array}{l}\text { Day } 1 \\
12: 32\end{array}$ & Before filter & Air & 0.4 & 1.1 & 1.5 \\
\hline $\begin{array}{l}\text { Day } 1 \\
12: 36\end{array}$ & After filter & Air & 0.4 & 1.0 & 1.4 \\
\hline $\begin{array}{l}\text { Day } 3 \\
10: 52\end{array}$ & Before filter & $21 \mathrm{v} \% \mathrm{O}_{2}-\mathrm{CO}_{2}$ & 0.3 & 1.8 & 2.1 \\
\hline $\begin{array}{l}\text { Day } 3 \\
10: 57\end{array}$ & After filter & $21 \mathrm{v} \% \mathrm{O}_{2}-\mathrm{CO}_{2}$ & 0.4 & 2.4 & 2.8 \\
\hline $\begin{array}{l}\text { Day } 3 \\
11: 36\end{array}$ & Before filter & $21 \mathrm{v} \% \mathrm{O}_{2}-\mathrm{CO}_{2}$ & 0.2 & 1.6 & 1.8 \\
\hline $\begin{array}{l}\text { Day } 3 \\
11: 41\end{array}$ & After filter & $21 \mathrm{v} \% \mathrm{O}_{2}-\mathrm{CO}_{2}$ & 0.2 & 1.3 & 1.5 \\
\hline $\begin{array}{l}\text { Day } 3 \\
12: 07\end{array}$ & Before filter & $21 \mathrm{v} \% \mathrm{O}_{2}-\mathrm{CO}_{2}$ & 0.2 & 1.8 & 2.0 \\
\hline $\begin{array}{l}\text { Day } 3 \\
12: 12\end{array}$ & After filter & $21 \mathrm{v} \% \mathrm{O}_{2}-\mathrm{CO}_{2}$ & 0.2 & 1.3 & 1.5 \\
\hline
\end{tabular}

Table 10 - Measurements for sulphur in the product gas. 


\section{Conclusions}

The Viking gasifier has been successfully converted from its original air-blown configuration to using $\mathrm{O}_{2}-\mathrm{CO}_{2}$ as gasification medium. Literature, modeling and experimental studies showed that operating conditions were expected to be in the range of air-blown values at $21-30 \mathrm{v} \% \mathrm{O}_{2}$-in- $\mathrm{CO}_{2}$, with partial oxidation and grate temperatures reduced by $52-69^{\circ} \mathrm{C}$ and $31-36^{\circ} \mathrm{C}$ respectively at $21 \mathrm{v} \% \mathrm{O}_{2}$. Detailed gas analysis for tar and sulphur species showed that the gas qualities during $\mathrm{O}_{2}-\mathrm{CO}_{2}$ operation were comparable to the very high standards of the typical air-blown mode at $<11 \mathrm{mg} / \mathrm{Nm}^{3}$ and $<3 \mathrm{ppm}$ respectively - without any downstream gas cleaning equipment.

Hence the system can be successfully converted to operate with an $\mathrm{O}_{2}-\mathrm{CO}_{2}$ blend without major additions to existing design. Compared to the more typically applied $\mathrm{O}_{2}-\mathrm{H}_{2} \mathrm{O}$ medium in the literature, applying $\mathrm{CO}_{2}$ might be better suited for some applications, as the media can be: 1) conveniently recirculated back to the oxygen source without need for high evaporation heat; 2 ) be completely converted into biofuels by addition of electrolytic hydrogen downstream of the system.

\section{Acknowledgements}

The authors would like to thank the ForskVE-programme of Energinet.dk for financial support through the Biomass Gasification Polygeneration project (ForskVE-12205).

\section{References}

[1] Basu P. Biomass Gasification, Pyrolysis and Torrefraction. Second Edi. Dalhouse University: Elsevier Inc.; 2013.

[2] Held J. Gasification - Status and technology. 2012. doi:1102-7371.

[3] Haldor Topsøe. From solid fuels to substitute natural gas (SNG) using TREMP. 2009.

[4] Rabou LPLM, Van der Drift B, Van Dijk EHAJ, Meijden CM Van der, Vreugdenhil BJ. Synthetic Natural Gas from Coal, Dry Biomass, and Power-to-Gas Applications. First edit. John Wiley \& sons Ltd; 2016.

[5] Devi L, Ptasinski KJ, Berends RH, Padban N, Beesteheerde J, Veringa HJ. Primary measures to reduce tar formation in fluidised-bed biomass gasifiers. 2004.

[6] Zwart RWR. Gas cleaning downstream biomass gasification Status Report 2009. 2009.

[7] Aravind PV, de Jong W. Evaluation of high temperature gas cleaning options for biomass gasification product gas for Solid Oxide Fuel Cells. Prog Energy Combust Sci 2012;38:737-64. doi:10.1016/j.pecs.2012.03.006.

[8] Kienberger T, Zuber C. Synthetic Natural Gas from Coal, Dry Biomass, and Power-to-Gas Applications. 1st ed. John Wiley \& sons inc.; 2016. doi:10.1002/9781119191339.

[9] Schildhauer TJ. Synthetic Natural Gas from Coal, Dry Biomass, and Power-to-Gas Applications. John Wiley \& sons inc.; 2016. doi:10.1002/9781119191339.

[10] Hofbauer H, Rauch R, Ripfel-Nitsche K. Report on Gas Cleaning for Synthesis Applications : Gas treatment 2007:75.

[11] Henriksen U, Ahrenfeldt J, Jensen TK, Gøbel B, Bentzen JD, Hindsgaul C, et al. The design, construction and operation of a 75 kW two-stage gasifier. Energy 2006;31:1542-53. doi:10.1016/j.energy.2005.05.031. 
[12] Ahrenfeldt J, Henriksen UB, Jensen TK, Gøbel B, Wiese L, Kather A, et al. Validation of a continuous combined heat and power (CHP) operation of a Two-Stage biomass gasifier. Energy \& Fuels 2006;20:2672-80.

[13] Bentzen JD, Brandt P, Gøbel B, Henriksen UB, Hindsgaul C. Optimering af $100 \mathrm{~kW}$ totrinsforgasningsanlæg på DTU: Resultater fra forsøg i uge 37 1998. 1999.

[14] Kiga T, Takano S, Kimura N, Omata K, Okawa M, Mori T, et al. Characteristics of pulverized-coal combustion in the system of oxygen/recycled flue gas combustion. Energy Convers Manag 1997;38:S129-34. doi:10.1016/S0196-8904(96)00258-0.

[15] Liu H, Zailani R, Gibbs BM. Comparisons of pulverized coal combustion in air and in mixtures of $O$ 2/CO 2. Fuel 2005;84:833-40. doi:10.1016/j.fuel.2004.11.018.

[16] Tan Y, Croiset E, Douglas MA, Thambimuthu K V. Combustion characteristics of coal in a mixture of oxygen and recycled flue gas. Fuel 2006;85:507-12. doi:10.1016/j.fuel.2005.08.010.

[17] Suda T, Masuko K, Sato J, Yamamoto A, Okazaki K. Effect of carbon dioxide on flame propagation of pulverized coal clouds in CO2/O2 combustion. Fuel 2007;86:2008-15. doi:10.1016/j.fuel.2006.11.038.

[18] Brix J. Oxy-Fuel Combustion of Coal. Technical University of Denmark, 2011.

[19] Pohorely M, Jeremias M, Svoboda K, Kamenikova P, Skoblia S, Beno Z. CO2 as moderator for biomass gasification. Fuel 2014;117:198-205. doi:10.1016/j.fuel.2013.09.068.

[20] Hanaoka T, Hiasa S, Edashige Y. Syngas production by CO 2 / O 2 gasi fi cation of aquatic biomass 2013;116:9-15. doi:10.1016/j.fuproc.2013.03.049.

[21] Technical University of Denmark. Homepage of the thermodynamic simulation tool DNA. DNA - A Therm Energy Syst Simulator 2009. http://orbit.dtu.dk/en/publications/id(b76040a4-5a29-4b04a898-12711391c933).html (accessed March 24, 2017).

[22] Elmegaard B, Houbak N. DNA - A General Energy System Simulation Tool. DNA - A Gen. Energy Syst. Simul. Tool, SIMS 2005 and Tapir Academic Press; 2005, p. 43-52.

[23] Gøbel B. Dynamisk modellering af forgasning i fixed koksbed. Technical University of Denmark, 1999.

[24] Elmegaard B. Simulation of boiler dynamics - Development, evaluation and application of a general energy system simulation tool. Technical University of Denmark, 1999.

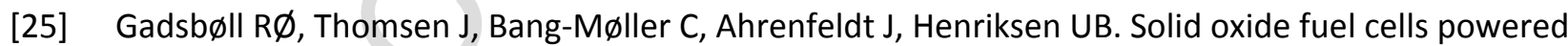
by biomass gasification for high efficiency power generation. Energy 2017;131:198-206. doi:10.1016/j.energy.2017.05.044.

[26] Campoy M, Gómez-Barea A, Vidal FB, Ollero P. Air-steam gasification of biomass in a fluidised bed: Process optimisation by enriched air. Fuel Process Technol 2009;90:677-85. doi:10.1016/j.fuproc.2008.12.007.

[27] Brandt P, Larsen E, Henriksen U. High tar reduction in a two-stage gasifier. Energy and Fuels 2000;14:816-9. doi:10.1021/ef990182m.

[28] Bentzen JD, Hummelshøj R, Henriksen UB, Gøbel B, Ahrenfeldt J, Elmegaard B. Upscale of the TwoStage Gasification. Proc. 2nd world Conf. Technol. Exhib. biomass energy Ind., 2004. 
[29] Klinghoffer N, Castaldi MJ, Nzihou A. Catalyst Properties and Catalytic Performance of Char from Biomass Gasification. I\&Ec 2012:13113-22. doi:10.1021/ie3014082.

[30] Mastral A, García T, Callén M, Navarro M, Galbán J. Assessement of Phenanthrene Removal from Hot Gas by Porous Carbons. Energy \& Fuels 2001;15:1-7. doi:10.1021/ef000116g.

[31] Mastral AM, García T, Callén MS, Navarro M V., Galbán J. Removal of naphthalene, phenanthrene, and pyrene by sorbents from hot gas. Environ Sci Technol 2001;35:2395-400.

doi:10.1021/es000152u.

[32] Hofmann P, Schweiger a., Fryda L, Panopoulos KD, Hohenwarter U, Bentzen JD, et al. High temperature electrolyte supported Ni-GDC/YSZ/LSM SOFC operation on two-stage Viking gasifier product gas. J Power Sources 2007;173:357-66. doi:10.1016/j.jpowsour.2007.04.073.

[33] Bang-Moeller C. Design and Optimization of an Integrated Biomass Gasification and solid oxide fuel cell system. Technical University of Denmark, 2010.

[34] The Danish Gas Legislation. Bekendtgørelse Om Gasreglementets Afsnit C-12, Bestem Om Gaskvaliteter n.d. https://www.retsinformation.dk/Forms/R0710.aspx?id=144715 (accessed July 31, 2017). 
Highlights of the article "Oxygen-blown operation of the TwoStage Viking gasifier"

- Air and $21-25 \mathrm{v} \% \mathrm{O}_{2}$-in- $\mathrm{CO}_{2}$ as gasification media yielded comparable operation

- Operational temperatures were slightly lower for $\mathrm{O}_{2}-\mathrm{CO}_{2}$-blown operation

- Tar and sulphur concentrations measured to $<11 \mathrm{mg} / \mathrm{Nm}^{3}$ and $<3 \mathrm{ppm}$ respectively 